Долгов Андрей Михайлович

кандидат юридических наук, доцент кафедры уголовного процесса Кубанского государственного университета

\section{О ВЫПОЛНЕНИИ КАПИТАНАМИ СУДОВ ПОЛНОМОЧИЙ ОРГАНОВ ДОЗНАНИЯ}

\section{Аннотация:}

В статье рассматриваются проблемные вопросы осуществления полномочий органа дознания капитанами судов, находящихся в дальнем плавании. Актуальность темы объясняется тем, что именно капитан судна является лицом, ответственным за безопасность судна, экипажа, пассажиров, и на него возложена задача поддержания порядка на судне. Проблема обеспечения безопасности судоходства и мореплавания является одной из важнейших на морском транспорте, так как от ее успешного решения зависят охрана жизни и здоровья членов экипажей судов и пассажиров, сохранность самих транспортных средств и перевозимых грузов, имущества судовладельцев, членов экипажей и пассажиров. Одним из элементов безопасности на судне является обеспечение соблюдения норм законодательства об уголовном судопроизводстве в случае обнаружения фактов совершения уголовно наказуемых противоправных деяний на судне. В этих целях именно капитан судна наделен широким кругом административных полномочий, а также является лицом, осуществляющим функции органа дознания на судне. На капитана судна возложены полномочия по возбуждению уголовного дела и производству неотложных следственных действий. В работе изучаются и с критической точки зрения оцениваются нормы уголовно-процессуального законодательства РФ и действующий нормативно-правовой акт, принятый еще в СССР, регламентирующие данную сферу деятельности. Предлагается внести изменения в действующее законодательство и принять новый подзаконный нормативно-правовой акт, регламентирующий особенности осуществления капитаном судна, находящегося в дальнем плавании, полномочий органа дознания.

Ключевые слова:

капитан, судно, безопасность, дальнее плавание, орган дознания, полномочия, функции, неотложные следственные действия, осмотр, место происшествия, труп, возбуждение уголовного дела.
Dolgov Andrey Mikhailovich

PhD in Law, Associate Professor, Criminal Process Department, Kuban State University

\section{THE IMPLEMENTATION OF THE POWERS OF INQUIRY BODIES BY SEA CAPTAINS}

\begin{abstract}
Summary:
The paper discusses the implementation of the powers of inquiry bodies by sea captains during the long voyage. The relevance of this topic is explained by the fact that it is the sea captain who is responsible for the safety of the ship, crew, passengers and is to keep order on the ship. Ensuring the navigation safety is the pivotal issue for maritime transport, since its successful solution depends on the protection of life and health of crew members and passengers, the safety of vehicles and cargo, the property of shipowners, crew members, and passengers. One of the elements of the ship security is the compliance with the criminal legislation when criminal offences are detected on board. To this end, a sea captain has a wide range of administrative powers and is a person that implements the powers of inquiry bodies on the ship. A ship's captain is empowered to initiate the criminal proceedings and conduct an immediate investigation. The study reviews and criticizes the standards of the criminal procedure legislation of the Russian Federation and current regulation of this type of activity adopted in the USSR. It is proposed to amend current legislation and adopt a new subordinate law regulating the powers of inquiry bodies implemented by a sea captain during the long voyage.
\end{abstract}

Keywords: captain, ship, safety, long voyage, inquiry bodies, powers, functions, immediate investigation, inspection, crime scene, corpse, initiation of criminal proceedings.

7 августа 1974 г. генеральным прокурором СССР утверждена Инструкция, которая регламентирует выполнение полномочий органов дознания на находящихся в плавании морских судах (далее - Инструкция) [1]. На момент утверждения Инструкции в СССР действовали УПК РСФСР и УПК союзных республик. Россия инкорпорирует в действующее законодательство нормы права СССР в той части, в которой эти нормы не противоречат законодательству РФ.

За почти полувековой период законодательство претерпело ряд основательных изменений. Только принятый 2001 г. УПК РФ более чем 200 раз подвергся различным изменениям [2].

УПК РФ закреплена обязанность капитана судна, находящегося под Государственным флагом РФ, по возбуждению уголовного дела и проведению неотложных следственных действий.

Белорусский ученый, профессор В.Н. Бибило считает, что «проведение следственных действий необходимо для установления обстоятельств, связанных с совершенным либо предположительно совершенным преступлением» [3, с. 452]. П.А. Лупинская полагает, что указанные 
права должны определяться как неотложные в каждом конкретном деле, так как «нельзя заранее определить, какое действие является неотложным в том или ином случае» [4, с. 237].

С учетом того, что на настоящий момент отсутствуют какие-либо вновь принятые нормативные акты, адресованные капитанам российских судов, необходимо руководствоваться УПК РФ, а также Инструкцией в той части, в которой она не противоречит УПК РФ.

Более детальное изучение норм Инструкции позволяет выявить следующие несоответствия ее положений УПК РФ.

Так, Инструкция подлежит применению в случае совершения деяния на судах, находящихся в плавании. УПК РФ предоставляет капитану судна определенные полномочия только в случае нахождения судна в дальнем плавании.

Инструкция распространяет свое действие на капитана судна или уполномоченное им лицо, а УПК РФ - только на капитана судна.

Инструкция, в отличие от УПК РФ, подразумевает наделение капитана судна всеми функциями органа дознания.

Инструкция допускает участие в следственных действиях потерпевшего, однако для признания лица потерпевшим необходимо соответствующее процессуальное решение, выраженное в постановлении о признании потерпевшим. Между тем по смыслу УПК РФ признание потерпевшим не относится к неотложным следственным действиям.

В Инструкции отсутствуют нормы, регламентирующие действия капитана корабля по соблюдению прав подозреваемого, состоящих в возможности использовать помощь защитника и консультироваться с ним наедине и конфиденциально. Также в Инструкции отсутствуют нормы, содержащие возможность допроса свидетеля с адвокатом.

Инструкция регламентирует порядок осмотра места происшествия, документов или предметов. Однако капитаном корабля, выполняющим полномочия органа дознания, может быть произведен осмотр непосредственно самого трупа в присутствии эксперта или при невозможности его участия - врача. Несомненно, что Инструкцией должны быть подробно урегулированы и описаны указанные ситуации.

Вызывает определенные вопросы производство обыска в помещениях, где проживают как члены экипажа, так и иные лица, находящиеся на судне (пассажиры, специальный персонал и др.), так как к жилищу, согласно ст. 5 УПК РФ, относится и помещение, которое используется в целях временного проживания, но не входит в жилищный фонд.

Вместе с тем необходимо отметить, что даже такой законодательный акт, как УПК РФ, устанавливающий общие положения по осуществлению полномочий капитаном судна и регламентирующий его процессуальный статус, не лишен, по нашему мнению, очевидных недостатков.

Так, уголовный процесс России состоит из системы стадий, которые следуют в определенном порядке друг за другом.

Стадия возбуждения уголовного дела начинается с регистрации сообщения о преступлении, а завершается принятием процессуального решения по результатам проверки вышеуказанного сообщения. По мнению О.В. Гладышевой, эту стадию не может миновать ни одно уголовное дело [5, с. 11]. В.А. Семенцов определяет сущность данной стадии как определение наличия материально-правовых и процессуальных предпосылок для начала предварительного расследования [6, с. 553]. По нашему мнению, процессуальным наполнением данной стадии являются действия уполномоченного или управомоченного лица, направленные на выявление признаков состава преступления. В зависимости от результатов принимается соответствующее решение.

Невозможно себе представить возбуждение уголовного дела без мероприятий по проверке сообщения о преступлении, так же как процесс проверки без самого сообщения о преступлении.

Между тем законом регламентировано полномочие капитана судна на возбуждение уголовного дела со ссылкой на ст. 146 УПК РФ, не содержащую порядка проведения проверки сообщения о преступлении. Указанная процессуальная фрорма предусмотрена ст. 144 УПК РФ, В которой предусмотрено, какие именно проверочные действия вправе производить лицо, проводящее проверку. Например, в случае обнаружения на судне трупа капитану судна необходимо произвести осмотр места происшествия, осмотр трупа, получить объяснения членов экипажа и пассажиров, что будет закреплено в соответствующих процессуальных документах. После производства указанных действий, установив наличие признаков преступления, капитан судна возбуждает уголовное дело и производит неотложные следственные действия, как, например, допрашивает лиц по обстоятельствам преступления. Он вправе изъять, осмотреть, приобщить к материалам дела необходимые вещественные доказательства и совершить другие действия.

По нашему мнению, капитану судна в обязательном порядке необходимо провести проверочные действия до возбуждения уголовного дела. Их проведение предоставлено законом строго определенному кругу лиц, в числе которых имеется орган дознания, но не капитан судна, которому предоставлены лишь отдельные полномочия органа дознания. 
Вызывает сомнение позиция Д.В. Червякова, полагающего, что капитан судна является органом дознания только лишь потому, что он упомянут в ст. 40 УПК РФ [7, с. 96]. Несмотря на то что капитан судна указан в ст. 40 УПК РФ, к органам дознания он не относится, так как на капитана судна, в соответствии с ч. 3 данной статьи, возложено лишь возбуждение уголовного дела. Отказать в возбуждении уголовного дела он не вправе, что также свидетельствует об отсутствии у капитана судна полномочий по проведению проверочных действий. УПК Республики Беларусь, например, прямо предусматривает, что капитан судна уполномочен законом на осуществление дознания [8].

Возбуждение уголовного дела без проверки может быть впоследствии признано незаконным, вследствие чего будут признаны незаконными и все доказательства, добытые капитаном судна. Трудно даже представить, какой вред может быть нанесен, если указанные действия будут проведены с нарушением закона и их результаты будут признаны недействительными.

Капитан судна должен быть наделен полномочиями по проверке сообщения о преступлении. Обнаружив признаки преступления, капитан судна первоначально должен зарегистрировать сообщение о преступлении, провести проверочные мероприятия, и в последующем, в соответствии с результатами проведенной проверки, либо возбудить уголовное дело, либо отказать в возбуждении. Кроме того, капитану судна надлежит предоставить отсутствующие у него полномочия по возбуждению уголовных дел категории частно-публичного обвинения. Так, например, при совершении на судне изнасилования, относящегося к подобной категории дел, капитан судна не вправе возбудить уголовное дело.

Несомненно, нормы права, регламентирующие осуществление процессуальных действий капитаном судна, нуждаются в изменениях, которые должны быть произведены по нескольким направлениям. Необходимы изменения и дополнения УПК РФ в части осуществления капитаном судна полномочий органа дознания. Также подлежит разработке и принятию концептуально новая инструкция, регламентирующая указанные правоотношения и соответствующая принципам уголовного судопроизводства России.

Представляется, что сформированный в рамках настоящей статьи комплекс предложений по совершенствованию роли капитана судна при производстве предварительного расследования позволит решить ряд вопросов, возникающих в правоприменительной деятельности.

\section{Ссылки:}

1. Инструкция о выполнении функций органов дознания на морских судах, находящихся в плавании [Электронный ресурс] : утв. Генпрокуратурой СССР 7 авг. 1974 г. Доступ из справ.-правовой системы «КонсультантПлюс».

2. Уголовно-процессуальный кодекс Российской Федерации. М., 2017.

3. Бибило В.Н. Проблемы юриспруденции : избранные труды. Минск, 2010. 469 с. (Серия «Научные труды белорусских ученых»).

4. Уголовный процесс : учебник / отв. ред. П.А. Лупинская. М., 2001. 696 с.

5. Гладышева О.В., Семенцов В.А. Уголовно-процессуальное право. Общая часть и досудебное производство : курс лекций. Краснодар, 2011. 350 с.

6. Семенцов В.А. Избранные статьи по уголовному процессу. Краснодар, 2013. 593 с.

7. Червяков Д.В. Капитан судна как орган дознания // Сборник докладов 60-й Международной молодежной научнотехнической конференции «Молодежь. Наука. Инновации» (Гуманитарная часть). Владивосток, 2013. Т. 2. С. 96-101.

8. Уголовно-процессуальный кодекс Республики Беларусь [Электронный ресурс] : от 16 июля 1999 г. № 295-3 : по сост. на 26 февр. 2018 г. URL: http://kodeksy.by/ugolovno-processualnyy-kodeks/ (дата обращения: 25.02.2018).

\section{References:}

Bibilo, VN 2010, Problems of jurisprudence, selected works, Minsk, 469 p., (in Russian).

Chervyakov, DV 2013, 'Sea captain as an inquiry body', Sbornik dokladov 60-i Mezhdunarodnoy molodezhnoy nauchnotekhnicheskoy konferentsii «Molodezh'. Nauka. Innovatsii» (Gumanitarnaya chast'), Vladivostok, vol. 2, pp. 96-101, (in Russian). Gladysheva, OV \& Sementsov, VA 2011, Criminal Procedure Law. The general part and pre-trial proceedings, a course of lectures, Krasnodar, 350 p., (in Russian).

Lupinskaya, PA (ed.) 2001, Criminal trial, textbook, Moscow, 696 p., (in Russian).

Sementsov, VA 2013, Selected articles on the criminal trial, Krasnodar, 593 p., (in Russian).

The Criminal Procedure Code of the Russian Federation 2017, Moscow, (in Russian). 